\title{
Resource dependency and institutional theory perspectives on direct and indirect export choices
}

\author{
Jolanda Hessels $\cdot$ Siri Terjesen
}

Accepted: 30 October 2008/Published online: 9 December 2008

(C) The Author(s) 2008. This article is published with open access at Springerlink.com

\begin{abstract}
This article develops and tests resource dependency and institutional theory arguments to explain two choices facing SME owner/managers: (1) the decision whether to export or not and (2) if the firm exports, the choice between a direct (to customers abroad) and an indirect (using another firm as intermediary) export mode. Binomial logistic regressions on our sample of 871 Dutch SMEs suggest that institutional theory perspectives (owner/managers' perception of the increased international presence of their domestic competitors, customers' and suppliers' and perceptions of increased use of foreign suppliers) explain the decision to export, while
\end{abstract}

Both authors contributed equally to this article.

J. Hessels ( $\square)$

EIM Business and Policy Research, Zoetermeer,

The Netherlands

e-mail: joh@eim.nl

\section{J. Hessels}

Erasmus School of Economics (Erasmus University),

Rotterdam,

The Netherlands

S. Terjesen

Indiana University, Bloomington, USA

e-mail: terjesen@indiana.edu

S. Terjesen

Max Planck Institute of Economics, Jena, Germany resource dependency theory arguments (owner/managers' perception of the favorability of access to knowledge and technology, of production costs and of access to capital in the home market) guide the choice between direct and indirect export modes.

Keywords Direct export - Indirect export . SMEs - Resource dependency theory ·

Institutional theory

JEL Classifications $\quad$ L2 $\cdot$ L26 $\cdot$ M16

\section{Introduction}

In comparison to large multinational enterprises (MNEs), small and medium-sized enterprises (SMEs) are typically regarded as resource-constrained, lacking market power, knowledge and resources to operate viably in international markets (Fujita 1995; Coviello and McAuley 1999; Knight 2000; Hollenstein 2005). Despite liabilities of small size and foreignness, an increasing number of SMEs pursue international markets to sell their goods and services (Reynolds 1997; Rugman and Wright 1999; OECD 2000). New and small firms' transaction costs of doing business abroad (e.g., costs associated with delivering goods or services to international customers) are particularly cumbersome (Zacharakis 1998); however, these costs 
have been reduced due to technological advances in telecommunication, transportation and information technology (Reynolds 1997; OECD 2000). Although there is a growing body of research on new and small firms' internationalization (Coviello and McAuley 1999; Rialp et al. 2005), extant research is largely confined to direct (e.g., exporting) means of internationalization (e.g., Bloodgood et al. 1996; McDougall and Oviatt 1996).

An emerging strand of research explores how new and small firms pursue an indirect path to internationalization (e.g., Acs et al. 1997; Peng and York 2001; Terjesen et al. 2008; Acs and Terjesen 2006) using local and foreign intermediaries to sell their goods and services across national borders. New and small ventures use intermediaries to overcome knowledge gaps, find customers and reduce the uncertainties and other risks associated with operating in foreign markets (Terjesen et al. 2008). Most intermediated internationalization studies are based on cases in a variety of country environments. Examples of indirect forms employed include local and foreign export intermediaries (Peng 2005; Bello and Lohtia 1995) and subsidiaries of multinational firms (Acs et al. 1997; Terjesen et al. 2008). An example of local firm intermediation is Dublin-based Cylon, a building control systems manufacturer that supplies products to a local subsidiary of $A B B$, which then sells the product around the world. A case of a foreign firm intermediary role is the Delhi-based software firm Softcell, which sells to the European headquarters of a Fortune 100 energy company that then distributes the product globally across the firm (Terjesen et al. 2008). In some countries, such as Japan and Korea, export intermediaries handle about half of total exports (Peng and Ilinitch 1998).

Extant research on new and small firm export activity explores the role of owner and firm-specific factors, such as learning (De Clercq et al. 2005), social capital (Yli-Renko et al. 2002) and ownership (George et al. 2005), mostly ignoring the role of the external environment (e.g., home market, organizational field). In the present exploratory study, we pose the following question: Does a SME owner/manager's perception of home market conditions and of the organizational field impact the decision to export and the mode of export? We build on two complementary frameworks: resource dependency theory and institutional theory. Based on resource dependency theory, we argue that factors relating to the perceptions of the home market environment may be relevant in explaining SME export activity and export mode. Institutional theory guides our contention that SME owner/manager perception of the degree of internationalization of the organization field affects the decision to export and the mode of export. We focus on explaining two choices facing SMEs: the decision whether to export or not, and the choice between direct and indirect export modes. We test resource dependency and institutional theory arguments using binomial logistic regression analyses for a sample of 871 SMEs headquartered in The Netherlands.

The article is structured as follows. Section 2 provides a brief overview of the literature on direct and indirect export modes. Section 3 presents and develops resource dependency and institutional theory arguments and puts forward four hypotheses predicting SME involvement in export activity and SME choice of export mode. Data and methodology are described in Sect. 4, and results are presented in Sect. 5. We frame a discussion in Sect. 6 and suggest implications for theory, practice, policy, and future research in Sect. 7.

\section{Direct and indirect export modes}

Firms have imperfect access to information, rendering foreign market entry a particularly risky and uncertain endeavor (Johanson and Vahlne 1977). Furthermore, extra costs, such as those associated with collecting foreign market information and seeking and evaluating local partners, can be burdensome, especially for resource-constrained SMEs. SMEs can pursue a variety of foreign market entry modes, such as exporting, licensing, joint venture, wholly owned subsidiary and greenfield investment. Entry modes vary significantly with respect to benefits and costs (Sharma and Erramilli 2004) and required resources (Blomstermo et al. 2006; Eriksson et al. 1997). In the case of exporting, firms face two channel options: (1) export directly to customers abroad or (2) export indirectly with the help of an intermediary (Peng and York 2001). As direct exporting is the most common path to SME internationalization and well-addressed in the extant literature, we focus on indirect means to internationalize. 
Indirect paths to internationalization are those "whereby small firms are involved in exporting, sourcing or distribution agreements with intermediary companies who manage, on their behalf, the transaction, sale or service with overseas companies" (Fletcher 2004, p. 290). Export intermediaries play an important "middleman" role in international trade, "linking individuals and organizations that would otherwise not have been connected" (Peng and York 2001, p. 328). Intermediaries link buyers and sellers in geographically distinct markets. Such indirect matching may be required to allow transactions to take place or to be successful (Trabold 2002). Intermediaries include agents and distributors located either at home or abroad (Peng and York 2001) and the local subsidiaries of MNEs.

Export intermediaries often help their clients to identify customers, financing and distribution infrastructure providers (Balabanis 2000). Export intermediaries also play a role in reducing knowledge gaps, uncertainties and other risks associated with operating in foreign markets. For example, export intermediaries can help to negotiate with foreign customers and to reduce commercial risks associated with a buyer's ability to pay. In addition, cost savings-related issues may also play a role. Firms may hire export intermediaries because they perform certain functions related to exporting better or at a lower cost than the firm itself could do, for example, because they possess country-specific knowledge that the firm lacks (Li 2004). Due to high export-related search and negotiation costs in distant markets, firms may be more likely to use export intermediaries (Peng and Ilinitch 1998). However, intermediaries also add to the cost of exporting, in particular transaction costs and rent extraction (Acs and Terjesen 2006). There could also be a loss of control when a firm uses an intermediary (Blomstermo et al. 2006). Compared to direct export, indirect modes involve lower levels of risk, control and resource commitment (Johanson and Wiedersheim-Paul 1975). In sum, using an intermediary is associated with both benefits (resulting from a reduction of risk, uncertainty and certain costs associated with operating abroad) and risks (following costs and lack of control that are associated with export intermediation). Export intermediaries may be particularly helpful for SMEs that lack resources and foreign market knowledge and thus face a more risky and uncertain path to internationalization (Peng and Ilinitch 1998). In contrast, SMEs that have clear competitive advantages from their home market may be less likely to need to rely on intermediaries.

Extant SME export research is mostly concerned with the direct mode and centers on firm-specific and owner-specific variables, including product uniqueness (Cavusgil and Nevin 1981), R\&D activity (Lefebvre and Lefebvre 2002), founder age (Westhead 1995) and top management team (TMT) experience in doing business abroad (Eriksson et al. 1997). A more limited body of research pursues the role of external factors, such as government support for internationalization (Wilkinson 2006), varieties of capitalism (Terjesen and Hessels 2009), environmental turbulence (Westhead et al. 2004) and the characteristics of foreign markets (e.g., the level of competition abroad) (Thirkell and Dau 1998) and domestic markets (e.g., production costs in the home market) (Axinn 1988). In contrast to earlier studies that involved limited sets of environmental factors, the present exploratory research develops and tests the perception of various aspects of the external environment based on two theoretical arguments: resource dependency and institutional theory.

\section{Theoretical background}

Resource dependency theory and institutional theory are both concerned with the relationship between an organization and a set of actors in the environment. Both theories assume organizational choice is constrained by multiple external pressures and that organizations are concerned with building legitimacy and acceptance vis-à-vis external stakeholders. The two theories have greater predictive power when used together (Sherer and Lee 2002). Resource dependency theory focuses on a firm's need to access resources from other actors in the environment and describes how resource scarcities force organizations to pursue new innovations that use alternative resources (Pfeffer and Salancik 1978; Sherer and Lee 2002). Institutional theory describes how an organization adopts practices that are considered acceptable and legitimate within its organizational field (Scott 1995). Thus, both theories describe how organizations face competitive pressures and may depend on, or be impacted by, other actors in the 
Table 1 Resource dependency and institutional theory

\begin{tabular}{|c|c|c|}
\hline & Resource dependency theory & Institutional theory \\
\hline Basic tenets & $\begin{array}{l}\text { Firms need to access resources in their environments. } \\
\text { Resource scarcities force organizations to pursue new } \\
\text { innovations that use alternative resources }\end{array}$ & $\begin{array}{l}\text { Organizations adopt practices that are } \\
\text { considered acceptable and legitimate in their } \\
\text { organizational field }\end{array}$ \\
\hline Seminal contributors & Pfeffer, Salancik & DiMaggio, Powell, Scott, Selznick \\
\hline Definition & $\begin{array}{l}\text { Resource: "tangible and intangible assets firms use to } \\
\text { conceive of and implement their strategies" (Barney and } \\
\text { Arikan 2001, p 138) }\end{array}$ & $\begin{array}{l}\text { Institution: "social structures that have attained } \\
\text { a high degree of resilience" that are } \\
\text { "composed of cultural-cognitive, normative, } \\
\text { and regulative elements that, together with } \\
\text { associated activities and resources, provide } \\
\text { stability and meaning to social life" (Scott } \\
\text { 1995, p 33) }\end{array}$ \\
\hline Assumptions & $\begin{array}{l}\text { Organizations make active choices to achieve objectives. } \\
\text { Organizations respond to demands made by other actors in } \\
\text { the environment. } \\
\text { Organizations try to minimize their dependence on } \\
\text { resources on which they are heavily dependent }\end{array}$ & $\begin{array}{l}\text { Organizations operate within a social } \\
\text { framework of norms, values, and } \\
\text { assumptions about what constitutes } \\
\text { appropriate behavior }\end{array}$ \\
\hline Our interpretation & $\begin{array}{l}\text { Perceived favorability of resource access in the home } \\
\text { market impacts firm strategy, including } \\
\text { internationalization }\end{array}$ & $\begin{array}{l}\text { Socially constructed beliefs and role systems } \\
\text { exert strong influence over organizations' } \\
\text { structure and conduct, including } \\
\text { internationalization. }\end{array}$ \\
\hline $\begin{array}{l}\text { Key findings } \\
\text { regarding firm } \\
\text { internationalization }\end{array}$ & $\begin{array}{l}\text { In the presence of cost differences, resource availability, } \\
\text { and utilization explain entry mode choice (Chang 1995; } \\
\text { Tesfom et al. 2004) }\end{array}$ & $\begin{array}{l}\text { Strategic business units that export, joint } \\
\text { venture or license have high levels of } \\
\text { external isomorphism to host country and } \\
\text { internal institutional environments (Davis } \\
\text { et al. 2000) }\end{array}$ \\
\hline $\begin{array}{l}\text { Common } \\
\text { assumptions }\end{array}$ & \multicolumn{2}{|c|}{$\begin{array}{l}\text { Organizational choice is constrained by multiple } \\
\text { external pressures. }\end{array}$} \\
\hline & \multirow{2}{*}{\multicolumn{2}{|c|}{$\begin{array}{l}\text { Organizations face competitive pressures and may depend } \\
\text { on/be impacted by other actors in the environment. } \\
\text { Organizations are concerned with building legitimacy } \\
\text { and acceptance vis-à-vis external stakeholders }\end{array}$}} \\
\hline & & \\
\hline
\end{tabular}

environment. However, the two theories differ in the explanations offered as to why organizations may be impacted by other actors. While resource dependency theory argues that dependence on other actors is related to need for resources, institutional theory predicts that organizations are inclined to imitate the behavioral norms of other actors in the organization field.

We expect these theories to be particularly relevant in explaining SME export behavior. First, due to size constraints, SMEs are particularly dependent on other actors in the environment for obtaining resources. Second, as SMEs tend to have many business linkages and are more susceptible to knowledge from external actors than their larger counterparts (Acs et al. 1994), we expect SMEs to be strongly influenced by the behavior, including the internationalization behavior, of surrounding actors. Table 1 provides an overview of the two theories and their relevance in explaining the phenomenon of direct and intermediated internationalization. ${ }^{1}$

\subsection{Resource dependency theory}

Consistent with the resource-based view of firms as bundles of unique resources that lead to competitive advantage, resource dependency theory focuses on the firm's ability to establish relationships to access resources (Van Witteloostuijn and Boone 2006). Resource dependency theory assumes that the organization makes active choices to achieve

\footnotetext{
$\overline{1}$ Thank you to an anonymous reviewer for the suggestion to incorporate a table.
} 
objectives. A major tenet of resource dependency theory is resource scarcity, resulting in multiple organizations competing for the same or similar sets of scarce resources. We follow Barney and Arikan (2001, p 138) in defining resources as the "tangible and intangible assets firms use to conceive of and implement their strategies." According to resource dependency theory, firms are dependent upon other actors in the immediate "task environment" to obtain resources. To survive, firms need to obtain resources from (actors in) the external environment. The focal organization will act to reduce or increase its level of reliance on those actors, through actions such as alliances or joint ventures. For example, as customers increasingly seek globally coordinated sourcing (Kotabe 1992), firms respond by creating alliances to strengthen relationships with key customers (Pfeffer and Salancik 1978) and suppliers, including following these customers overseas. This is why many of Toyota's Japan-based parts suppliers set up operations in the proximity of Toyota's automobile manufacturing facility in Kentucky.

Resource dependency theory can also be applied to consider a firm's need to obtain resources required for exporting (Tesfom et al. 2004). In this regard, resource dependency theory explains how a firm's location in a desirable home market can aid the accumulation of resources that are required to export. A large body of empirical research investigates how a SMEs current resource base impacts export activity (e.g., Cavusgil and Nevin 1981; Akoorie and Enderwick 1992; Chang 1995; Westhead 1995; Keeble et al. 1998; Autio et al. 2000; Tesfom et al. 2004); however, little is known about the relationship between availability of resources in the home market and firm export behavior. Building on resource dependency theory, we expect that SMEs are dependent upon the home market to obtain resources needed for exporting and may benefit when home environments are favorable and contain valued resources. We expect that as SMEs have limited firm resources, particularly when compared with large multinationals, they may be particularly reliant on the resources perceived to be available in their home country.

Porter (1990, 1998) describes how firms based in national markets enjoy certain competitive advantages. Two key components are the presence of related and supporting activities (e.g., presence of customers and suppliers) and certain factor conditions (e.g., availability of capital, knowledge, technology, resources, level of production costs, legal protection of property rights and quality of government regulation for business). Based on Porter (1990, 1998), we expect that the favorability of home market industry and factor conditions can enhance or constrain SMEs' abilities to export. For example, SMEs often depend on their home market environments for obtaining the finance, technology and raw material resources needed for exporting, and SMEs will benefit when these resources are perceived to be widely available and easily accessible in the home market. Also, SMEs depend upon production costs in the home environment, and when such costs are perceived to be favorable in the home market, propensity to export may increase since SMEs may be better able to develop internationally competitive products or services, at least as far as price is concerned. A firm's ability to export may also depend upon the extent of home market intellectual property protection (IP): SMEs based in home markets with strong IP rights protection may have an adequate context for developing international competitive products or services. In contrast, SMEs based in home markets with poorly perceived industry and factor conditions may be unable to establish relationships necessary to secure the "right" resource bundles to pursue international markets. These SMEs may then be unable or unwilling to take on the risks of foreign markets. Thus, we expect:

Hypothesis 1 A SME is more likely to export, directly or indirectly, when its home market conditions are perceived as favorable.

Furthermore, perceived home market favorability may impact the choice between direct and indirect export. Compared to the indirect mode, the direct mode of exporting requires firms possess a more full set of resources and capabilities (Acs and Terjesen 2006), and a SME must thus establish relationships to secure these. For example, when home market factor conditions, such as resource availability, production costs, intellectual property rights protection, government regulation and the presence of related and supporting industries are perceived as favorable, SMEs may be better able to access relationships to resources to develop products and competences that have competitive advantages vis-à-vis foreign firms and are exportable. Therefore, SMEs based in 
favorably perceived home markets may be more able and more willing to pursue foreign markets directly, rather than indirectly. Based on the above, we suspect:

Hypothesis 2 A SME is more likely to export directly when its home market conditions are perceived as favorable.

\subsection{Institutional theory}

According to institutional theory, organizations operate within a social framework of norms, values and assumptions about what constitutes appropriate behavior (Oliver 1997; Scott 1995). We follow Scott (1995: 33) in defining institutions as "social structures that have attained a high degree of resilience" that are "composed of cultural-cognitive, normative, and regulative elements that, together with associated activities and resources, provide stability and meaning to social life." Institutional contexts "prescribe and proscribe organizational alternatives" (Hinings and Greenwood 1988). Decisions are made not so much according to technical or economic criteria, but on the basis of what is acceptable and legitimate within a particular environment or "organization field" that typically moves toward common structures and processes due to coercive, imitative, and normative expectations (DiMaggio and Powell 1983). Traditionally, institutional researchers explored external institutions such as rules, regulatory structures and agencies, however the field has been extended to include other firms in the same industry or units within the same firm. Strategic business units that export, joint venture or license have high levels of external isomorphism to host country and internal institutional environments (Davis et al. 2000).

Firms face competing isomorphic pulls from local and global organization fields (Gimeno et al. 2005). Historically, a firm is identified with other actors in its local economy. Increasingly, as financial markets, competitors, and customers become more global in scope, the firm may be considered a member of a global organization field (Westney 2003). The implication is that the greater the pull from the global organization field, the more likely that the firm will export overseas.

Based on institutional theory, we suggest that to the extent a firm sees itself as part of a global (rather than local) organization field, the firm will progressively adopt the behaviors and processes that provide legitimacy within that field. Thus, firms may follow home country direct and substitute competitors, customers and suppliers overseas, and this process may include indirect paths. Also, an increased presence of foreign actors, such as foreign suppliers and foreign customers in the firm's direct task environment, indicates an increasingly global organization field and may subsequently provide the firm with legitimacy to service markets abroad. The idea that a firm may be more inclined to engage in export activities if it is exposed to other economic actors' international activities is also found in the emerging export spillovers literature on the impact of foreign multinational enterprises on domestic firms' export activity (e.g., Aitken et al. 1997; Greenaway et al. 2004; Kneller and Pisu 2007; De Clercq et al. 2008). The export spillover literature complements the institutional theory perspective by providing a broader perspective of the channels through which spillovers occur. More specifically, export spillover research recognizes a demonstration or imitation effect (as is suggested by institutional theory) and suggests that commercial linkages, training and increased competition from an international actor can increase a domestic firm's likelihood of exporting.

Hypothesis 3 A SME is more likely to export, directly or indirectly, when its organization field is perceived as increasingly global.

As described above, exporters can use intermediaries to reduce several sets of risks of foreign markets, such as a lack of information and ability to identify and communicate with customers. Building on the above expectation that operating in an increasingly global field may positively affect SME propensity to export, we anticipate that the perceived international orientation of the organization field may also affect the choice of direct or indirect export mode. A SME that operates in an increasingly global organization field may find it easier to directly access information on foreign markets and locate customers abroad. Consequently, the necessity of using intermediaries may be reduced, and the odds for using the direct mode may increase. Thus, we expect:

Hypothesis 4 A SME is more likely to export directly when its organization field is perceived as increasingly global. 


\section{Data and methodology}

\subsection{Data}

We invited a random sample of 1,665 Dutch SMEs (fewer than 250 employees) to participate in an Internet survey. We received usable responses from $871(52 \%)$. The Netherlands is a particularly interesting country for investigating internationalization due to the nature of its small, open economy. The Dutch business sector is strongly dependent on international trade and is among the world's largest international traders and foreign direct investors (UNCTAD 2008). Compared to SMEs based in other European countries, Dutch SMEs are only slightly more likely to export and import and on average invest abroad (Hessels 2005).

\subsection{Sample characteristics}

Of the Dutch SMEs in our sample, 9\% export indirectly and $22 \%$ export directly. SMEs with larger numbers of employees are more likely to export indirectly than their smaller counterparts. The proportion of SMEs involved in indirect exports is $5 \%$ for firms with up to 9 employees, $12 \%$ for firms with 10 49 employees and $21 \%$ for firms with 50-250 employees. There is no significant difference in participation in indirect export between young and old firms. (Following McDougall (1989); we define young firms as 8 or fewer years old.) In our sample, $8 \%$ of young firms and $10 \%$ of more established firms export indirectly. Furthermore, our indirect exporters are more likely to use foreign intermediaries as compared to domestic intermediaries. Twenty-seven percent of indirect exporters use both domestic and foreign intermediaries, while $17 \%$ indicate using only a domestic intermediary, and 56\% report using only a foreign intermediary. The use of agents $(62 \%)$ and
Table 3 SME motivations for using an intermediary

\begin{tabular}{lc}
\hline Motivation & $\%$ Agree \\
\hline $\begin{array}{l}\text { To find customers abroad } \\
\text { To diminish risk and uncertainty }\end{array}$ & 54 \\
$\quad$ of operating abroad & 42 \\
$\begin{array}{l}\text { To compensate for a lack of knowledge } \\
\quad \text { of certain markets within our organization }\end{array}$ & 38 \\
$\begin{array}{l}\text { To save costs for drawing up of contracts } \\
\quad \text { with clients abroad }\end{array}$ & 20 \\
$\begin{array}{l}\text { To save costs for conducting market research } \\
\text { To save costs for enforcement of contracts }\end{array}$ & 16 \\
$\quad$ with clients abroad & 8 \\
Other & 19 \\
Don't know & 4 \\
\hline
\end{tabular}

Note: $n=74$; more than one answer allowed

wholesaler/distributor/dealer/reseller (58\%) is most common, while only $12 \%$ use a(n) (office of a) multinational (see Table 2).

Table 3 reports SMEs' motivations for using an intermediary when exporting. The most frequently cited reason for using an intermediary is to find customers in foreign markets (mentioned by $54 \%$ of the indirect exporters in our sample). The use of intermediaries is also frequently reported to be a costsaving measure, which includes saving costs for drawing up and enforcing contracts with clients abroad and saving costs for conducting market research (together these cost-saving motives add up to $44 \%$ ). Other reasons for using intermediaries include diminishing the risk and uncertainty of operating overseas $(42 \%)$ and compensating for a lack of knowledge about foreign markets (38\%).

\subsection{Empirical analysis}

We test our hypotheses with binomial logistic regression analyses. The unit of analysis is the
Table 2 SME choice of intermediary

Note: $n=74$; more than one answer allowed

\begin{tabular}{lcccc}
\hline Type of intermediary & $\begin{array}{l}\text { Domestic } \\
(\%)\end{array}$ & $\begin{array}{l}\text { Foreign } \\
(\%)\end{array}$ & $\begin{array}{l}\text { Both foreign } \\
\text { and domestic } \\
(\%)\end{array}$ & $\begin{array}{l}\text { Total } \\
(\%)\end{array}$ \\
\hline Agent & 11 & 43 & 8 & 62 \\
Wholesaler/distributor/dealer/ & 11 & 36 & 11 & 58 \\
$\quad$ reseller & 5 & 4 & 3 & 12 \\
A(n) (office of a) multinational & 17 & 56 & 27 & 100 \\
Total & & & & \\
\hline
\end{tabular}


owner/manager reporting on his/her SME. For the purpose of our regression analysis, we omit "don't know" and missing values, resulting in a final sample of 402 valid observations.

\subsubsection{Measures}

\subsubsection{Dependent variables Export involvement:}

For export involvement, we construct a dummy variable composed of no export activities (0) and exports, both indirect and direct (1).

Export mode: For export mode, we construct a dummy variable with direct export (0) and indirect export (1). Direct exports include exports through a firm-owned foreign (sales) office abroad. The few firms in our sample that use both intermediaries and direct modes are classified as indirect exporters.

\subsubsection{Independent variables Perceived favorability} of the home market: Perception of favorability of the home environment in terms of factor conditions and the presence of related and supporting industries (Porter $1990,1998)$ is assessed by asking respondents for their perceptions of The Netherlands' business environment. We ask SME owners to assess the home market favorability for their firm in terms of the following items: presence of relevant customers, presence of relevant suppliers, presence of relevant resources and raw materials, access to investors and banks, access to knowledge and technology, cost of producing their goods or services, protection of intellectual property rights and quality of government regulation with respect to business. For each category, we construct a variable with "unfavorable" and "neither favorable, nor unfavorable" taken together (0) and favorable (1).

Perceived internationalization of the organization field: We construct a number of variables based on the respondents' assessment of the following question: "To what extent are the following statements applicable to your organization? Our competitors in The Netherlands operate to an increasing extent in foreign markets; our customers in The Netherlands operate to an increasing extent in foreign markets; our suppliers in The Netherlands operate to an increasing extent in foreign markets; our organization/subsidiary increasingly has to deal with foreign competition in the Dutch market; our organization/ subsidiary makes to an increasing extent use of suppliers from abroad." ${ }^{2}$ For each statement, a variable is constructed including "not applicable" (0) and "to some extent applicable" and "to a large extent applicable" taken together (1).

4.3.1.3 Control variables Industry dummies are constructed for production industries (manufacturing and construction), trade (retail and wholesale), business services and other industries (including transportation, lodging and financial services). "Other industries" is the reference group in the regression estimation. Various empirical studies report a positive association between firm size and export behavior (Chetty and Hamilton 1993; Westhead 1995; Lefebvre and Lefebvre 2002). We include controls for the firm's size (natural log of number of employees), age (natural log of firm age) and resource base (business owner's level of education, TMT foreign experience, presence of foreign investors). As previous research indicates that decision-makers in exporting firms tend to have higher levels of education than do decision-makers in non-exporting firms (Simpson and Kujawa 1974), we control for the business owner's level of education using dummy variables for low education (lower secondary degree or less), medium education (higher secondary degree or equivalent) and higher education (higher business education or university degree). We use

\footnotetext{
$\overline{2}$ Since extant literature lacks established measures for our independent variables and since we were unable to use detailed scales for our items in the survey, we do not present results for the use of composite, factor analysis-based measures of perceived home market favorability and perceived organizational field internationalization (in footnotes 3 and 4, however, we do give a description of the results we find when using such composite measures). Also, our use of unique individual measures provides insight into the specific influences of the separate variables on SME export, which is particularly useful given the exploratory nature of our study. For example, using a composite indicator for perceived internationalization of the organization field does not indicate that one of our individual variables, i.e., increased foreign competition in the home market, does not relate significantly to the probability to export, while the other individual measures do. Cronbach's alphas for perceived home market favorability and perceived internationalization of the organization field are 0.70 and 0.76 , respectively, indicating good fit. Tests indicate that multicollinearity is not a concern when we include all individual measures in our models. (See the results section for details.)
} 
"low education" as the reference category in the regression estimation. A dummy for TMT foreign experience is constructed capturing "no" or "hardly any experience" (0) and "some" or "much experience" (1). Finally, presence of foreign investors is recorded as no (0) and yes (1). Table 4 provides some descriptives for our main variables.

Table 4 Variable means and standard deviations

\begin{tabular}{|c|c|c|}
\hline & Mean & SD \\
\hline \multicolumn{3}{|l|}{ Dependent variables } \\
\hline Export involvement (no export, export) & 0.29 & 0.46 \\
\hline Export mode (direct export, indirect export) & 0.12 & 0.33 \\
\hline \multicolumn{3}{|l|}{ Controls } \\
\hline Production industries & 0.22 & 0.41 \\
\hline Trade industries & 0.19 & 0.39 \\
\hline Business services & 0.23 & 0.42 \\
\hline Other industries & 0.36 & 0.48 \\
\hline Log firm age & 2.88 & 0.91 \\
\hline Log firm size & 2.15 & 1.51 \\
\hline Business owner education (low) & 0.12 & 0.33 \\
\hline Business owner education (medium) & 0.29 & 0.46 \\
\hline Business owner education (high) & 0.58 & 0.49 \\
\hline TMT foreign experience & 0.28 & 0.45 \\
\hline Foreign investors & 0.06 & 0.24 \\
\hline \multicolumn{3}{|l|}{ Home market: perceived favorability } \\
\hline Presence of relevant customers & 0.65 & 0.48 \\
\hline Presence of relevant suppliers & 0.51 & 0.50 \\
\hline $\begin{array}{l}\text { Presence of relevant resources and raw } \\
\text { materials }\end{array}$ & 0.22 & 0.42 \\
\hline Access to investors & 0.36 & 0.48 \\
\hline Access to knowledge and technology & 0.55 & 0.50 \\
\hline Production costs & 0.08 & 0.27 \\
\hline Protection of intellectual property right & 0.25 & 0.43 \\
\hline Quality of government regulation for business & 0.15 & 0.36 \\
\hline \multicolumn{3}{|l|}{ Organization field: perceived internationalization } \\
\hline $\begin{array}{l}\text { Domestic competitors increasingly operate } \\
\text { abroad }\end{array}$ & 0.47 & 0.64 \\
\hline $\begin{array}{l}\text { Domestic customers increasingly operate } \\
\text { abroad }\end{array}$ & 0.53 & 0.71 \\
\hline $\begin{array}{l}\text { Domestic suppliers increasingly operate } \\
\text { abroad }\end{array}$ & 0.53 & 0.67 \\
\hline $\begin{array}{l}\text { Foreign competitors increasingly operate in } \\
\text { home market }\end{array}$ & 0.65 & 0.75 \\
\hline Increased use of foreign suppliers & 0.46 & 0.70 \\
\hline
\end{tabular}

Note: $n=402$ for all variables with the exception of export mode $(n=118)$

\section{Results}

\subsection{Logistic regression analyses}

We perform two types of logistic regression analyses in order to test our hypotheses. First, we use binomial logistic regression analysis, in which export involvement is the dependent variable, to investigate how our independent variables impact the odds of being involved in export as compared to not exporting and therefore take "no export" as the reference category (Hypotheses 1 and 3). Second, we apply binomial logistic regression analysis with export mode as the dependent variable in order to investigate whether the odds of being involved in indirect export relative to direct export are influenced by our explanatory variables (Hypotheses 2 and 4).

\subsection{Export versus no export}

Table 5 presents the estimation results of the binomial logistic regression with export involvement as the dependent variable. We tested for multi-collinearity using variance inflation factors (VIFs). No VIF above 10 is observed (the highest VIF is 2.628), indicating that multi-collinearity is not a concern. The tables present both the log odds ratios and the odds ratios. The coefficients in Table 5 indicate the effect of a corresponding variable on the odds (ratio of two probabilities) of indirect export and direct export relative to the "no export" base category. The odds ratios should be interpreted as follows. A coefficient above unity (corresponding to a log odds ratio above zero) implies that the corresponding variable increases the odds of belonging to the category in question relative to the "no export" group. A coefficient below unity implies that the variable decreases the odds of belonging to the category in question relative to "no export." In the table, we add the variable groups in incremental steps. In model 1 (the base model), we only include the control variables. In model 2 we add our variables for perceived favorability of the home market to the base model, while in model 3 we include our variables for perceived internationalization of the organization field (leaving out the variables for perceived favorability of the home market). Finally, in model 4 we add both groups of variables to the base model. Results are presented in Table 5. 


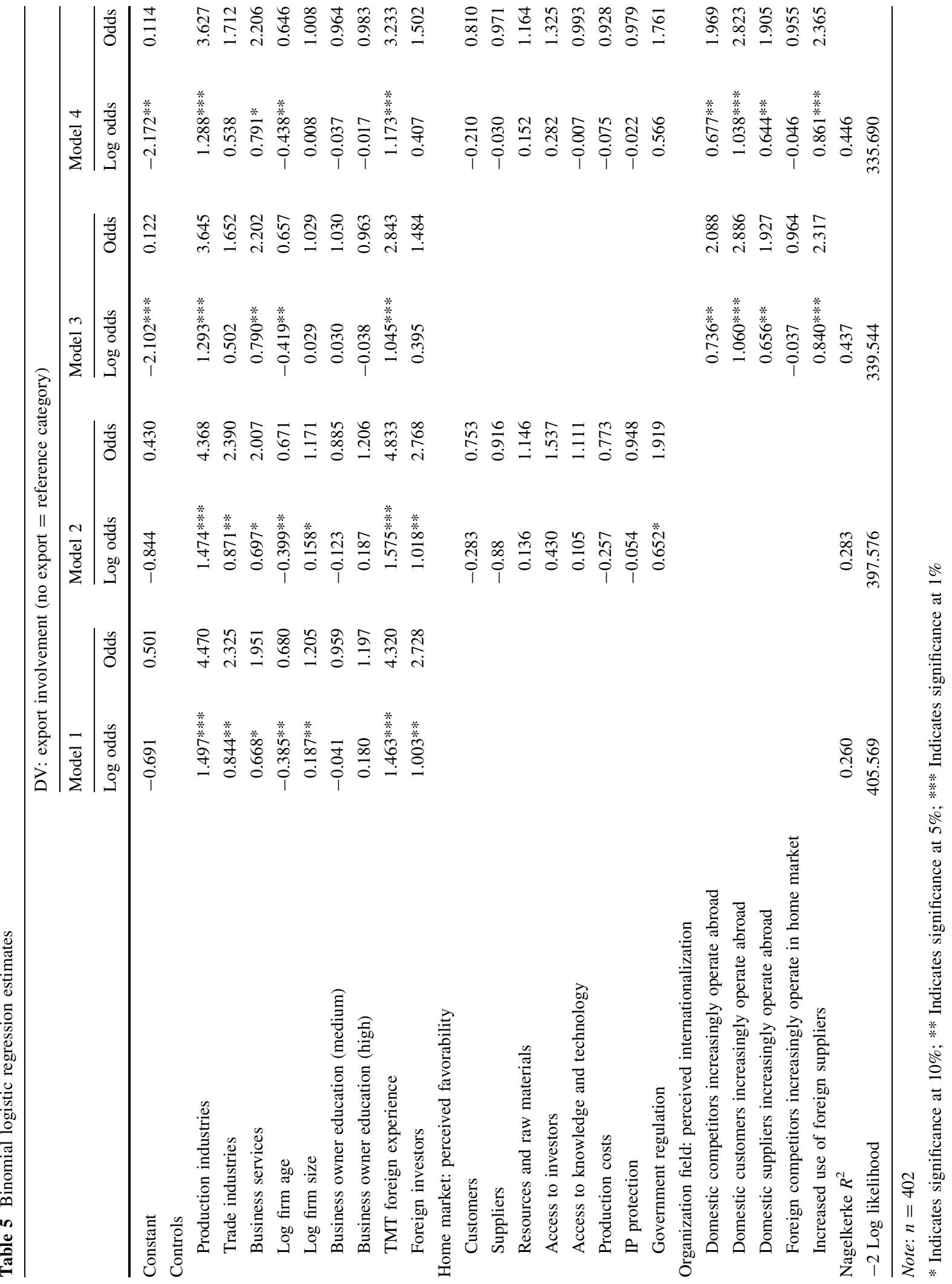


Results for the base model (model 1) show that firms belonging to production industries (manufacturing, construction), trade industries and business services are significantly more likely to export than those belonging to the reference category "other industry." Furthermore, firm age decreases the odds of being involved in exports relative to no exports, indicating that younger firms are more likely to export than older firms. Also, firm size relates positively to export. Regarding the firm's resource base, our results indicate that firms with TMT members with experience of working and living abroad are more likely to export as well as firms having foreign investors.

Table 5 further reveals that when our variables for perceived favorability of the home market are added in model 2 , the $R^{2}$ of the model only slightly increases compared to model 1 (from 0.260 to 0.283 ). However, the $R^{2}$ of the model increases to 0.437 in model 3 (as compared to 0.260 in model 1) when our variables for perceived internationalization of the organization field are added. Likelihood ratio tests show that the improvement of the model fit for model 3 relative to model 1 is significant when our variables for perceived internationalization of the organization field are added (tests statistics equal 66.03, while the critical value at the $1 \%$ level is 15.09 (5 degrees of freedom)), while the increase in model fit is not significant for model 2 in which our variables for perceived favorability of the home market are added to the base model. The increase in model fit for model 4 (as compared to model 1) is also significant, which is attributable to the inclusion of the variables for perception of the organization field. ${ }^{3}$

\footnotetext{
${ }^{3} \mathrm{We}$ also did some exercises using factor analysis-based composite measures for perception of favorability of the home environment and for perception of globalization of the organization field. These results reveal that the composite measure for perceived favorability of the home market displays no significant association with the probability to export, whereas the composite measure for perceived globalization of the organization field shows a significant positive association with export involvement. However, given the exploratory nature of our study, we feel that it is more interesting to show the results for the individual measures as this reveals that one of our measures (increased foreign competition) has no significant relationship to the probability to export. Since literature lacks established measures for our independent variables, we feel that showing individual results will help researchers in further developing and testing measures in future research. Therefore, it was decided to only show the results
}

Coming back to our hypotheses, we find no significant relationship between export and any of the indicators for home market favorability in either model 2 or $4 .^{4}$ Thus, we find no support for Hypothesis 1.

Regarding the perceived globalness of the organizational field, model 3 shows that firms whose owner/ manager perceives having competitors, customers and suppliers that increasingly operate abroad, and firms that make increased use of foreign suppliers are more likely to export (as compared to no export activity). These results still hold when the variables for perceived favorability of the home market are added in model 4. Thus, we find some support for Hypothesis 3 , suggesting that a more global organization field may positively impact SME involvement in export.

\subsection{Indirect export versus direct export}

Binomial logistic regression results of the choice between direct and indirect export are displayed in Table 6. The valid sample consists only of exporters and is 118. Again we employed multi-collinearity tests using variance inflation factors (VIFs). VIFs are below 10 (the highest VIF is 3.225), which indicates that multi-collinearity is not a concern. Again we add our group of variables in incremental steps. While model 5 (base model) only includes the control variables, in model 6 our variables for perceived favorability of the home market are added to this base model; in model 7 our variables for perception of the organization field are added to the base model (leaving out variables for perceived favorability of the home market), and in model 8 we include all groups of variables. Results are presented in Table 6 .

Model 5, which includes only the control variables, shows that none of the controls has a significant impact on the choice between direct and indirect export. The $R^{2}$ increases from 0.146 in model 5 to 0.278 in model 6 , and likelihood ratio tests reveal

\footnotetext{
Footnote 3 continued

containing individual measures, and we do not display results using composite measures. In addition, individual level results are also more informative for policymakers and business owners/practitioners. See also footnote 2 .

${ }^{4}$ Note that in model 2, perceived favorability of government regulation is significant at $10 \%$. However, this variable is no longer significant in model 4 when the variables for perceived globalization of the organization field are added.
} 


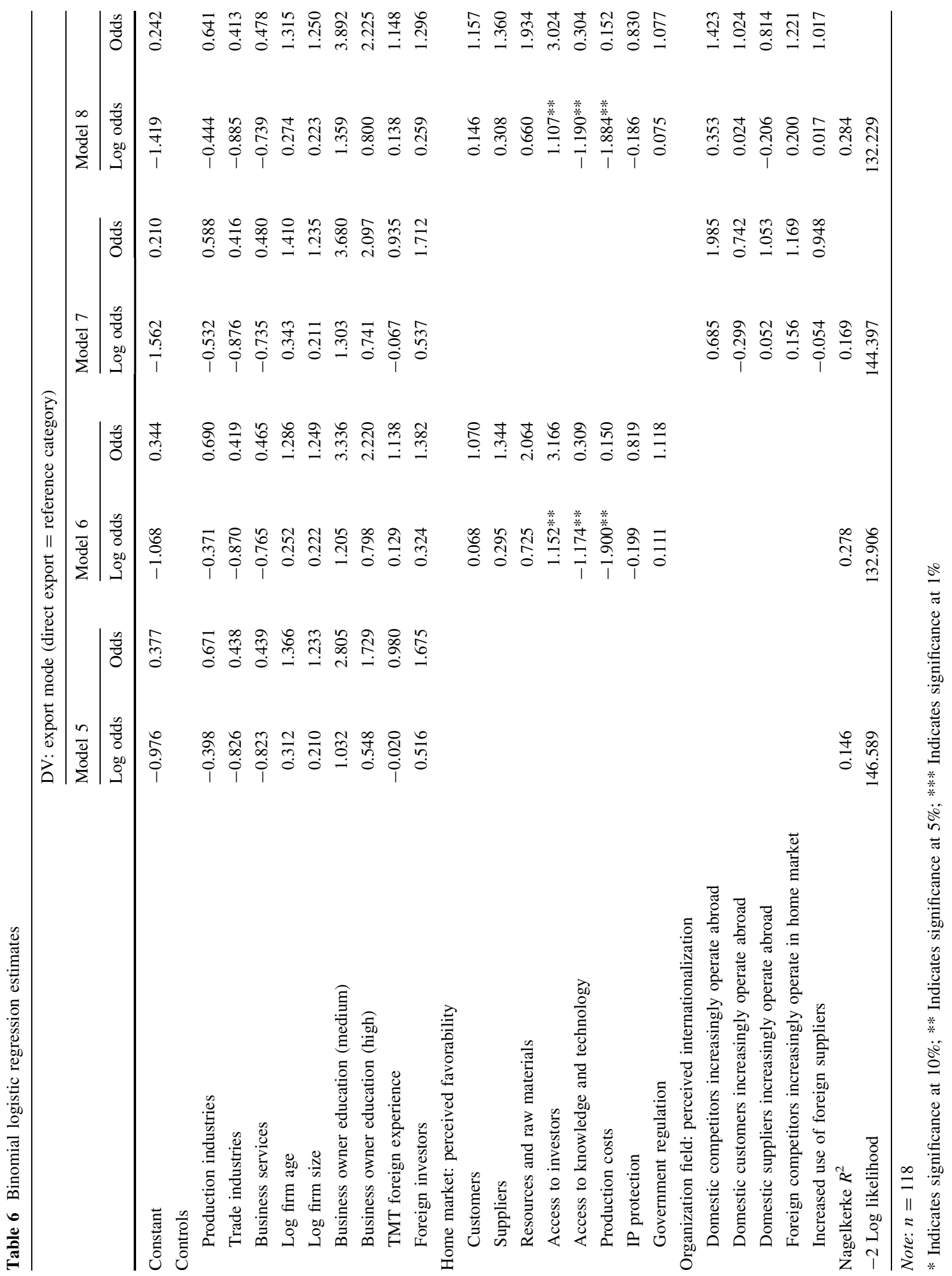


that this increase in model fit is significant [tests statistics equal 13.68, while the critical value at the $10 \%$ level is 13.36 ( 8 degrees of freedom)]. However, it can also be seen that only three of the eight variables for perceived home market favorability display a significant relationship with the dependent variable. In particular, we find that perceived favorability of access to investors and banks at home increases the probability for indirect export (relative to direct export), whereas perceived favorability to knowledge and technology and perceived favorability of production costs in the home market decrease the probability of indirect export (relative to direct export). These results hold up in model 8 when the variables for the organization field are also included.

Furthermore, the results show that the $R^{2}$ for model 7 is 0.169 , which is a slight increase as compared to model $5\left(R^{2}=0.146\right)$, and likelihood ratio tests reveal that the increase in model fit of model 7 relative to model 5 is not significant. Model 7 also shows that none of the variables for perception of the organization field have a significant relationship with the dependent variable, and this remains unchanged in model 8 , which also includes the variables for perceived home market favorability. ${ }^{5}$

Thus, coming back to our hypotheses, overall, we find, contrary to Hypothesis 2, that SME likelihood of indirect rather than direct export modes increases with the perceived favorability of access to domestic investors and banks. On the other hand, in line with Hypothesis 2, we find that propensity to export, indirectly relative to directly, decreases when home market production costs and access to knowledge and technology are perceived as being favorable. Furthermore, although an increasingly global organization

\footnotetext{
5 Again, we also did some exercises using composite factor analysis-based measures for perception of favorability of the home environment and for perception of globalization of the organization field. These results reveal that the composite measures have no significant relationship with export mode. However, since the literature lacks established measures for our independent variables, since empirical research on explaining export mode choice is limited, and since when using individual measures we do find a significant impact for three of our variables for perceived favorability of the home market, we feel that showing results for individual measures is more informative for researchers interested in explaining export mode choice. In addition, showing individual level results is also more informative for policy makers and business owners/ practitioners.
}

field affects export involvement, we find no effect on the choice between direct and indirect modes. In sum, these results provide partial support for Hypothesis 2, but no support for Hypothesis 4.

\section{Discussion}

This study has provided insight into SME participation in direct and indirect export modes. One of our main findings is that SMEs operating in an organization field that is perceived as being increasingly global are more likely to export. A firm operating in a field in which domestic customers and domestic competitors are perceived to be increasingly global, for example, is more likely to export. This finding may indicate that SMEs follow domestic customers and competitors to overseas markets. Having domestic suppliers that increasingly operate abroad is also positively related to export activity, which may indicate that suppliers share, for example, their knowledge of foreign markets and distribution channels with their contractor firms. Our study indicates that firms that increasingly use foreign suppliers are more likely to export. This is in line with findings from past research that indicate that foreign purchasing may stimulate export (Korhonen et al. 1996). Taken as a whole, these findings complement the limited existing literature on export spillovers that focuses primarily on the impact of foreign multinationals on domestic firm's export activity (e.g., Aitken et al. 1997; Greenaway et al. 2004; Kneller and Pisu 2007; De Clercq et al. 2008). Our findings suggest that export spillovers to SMEs originate from domestic competitors, customers and suppliers as well as from foreign suppliers and indicate that studies on export spillovers should consider the various actors that are active in the firm's immediate task environment. As national economies grow more interconnected, organizational fields will be increasingly globalized, and SME involvement in international markets is likely to expand.

Surprisingly, although we find a positive impact on SME export when domestic competitors are perceived as increasingly global, we have no evidence that amplified foreign competition in the home market increases the odds of SME export. Globalization implies that SMEs face greater foreign competition in the home market (Etemad 2004). 
It was our expectation that a perception of increased foreign competition would stimulate firms to look beyond domestic markets and to adopt an international focus (Etemad 2005); however, our data do not support this. Possibly (a perception of) increased foreign competition in the home market stimulates domestic SMEs to increase their performance in the domestic market (in which they are facing the foreign competition) to be able to effectively deal with the threats normally inherent in such competition, rather than to internationalize. It could also be the case that a perception of increased foreign competition is likely to be found among SME business owners that tend to be risk averse and pessimistic, and that this mitigates the effect of competition on exporting. We acknowledge that these explanations are somewhat speculative and encourage future researchers to shed more light on the impact of foreign competition on the operations of domestic SMEs, including on their internationalization behavior.

Contrary to our initial expectations, we find no evidence that perceived favorability of the home market (e.g., in terms of the presence of relevant customers and suppliers and resource access and availability) affects SME export involvement. This may suggest that in the current global economy SMEs are perhaps no longer as dependent upon their home environments for generating international competitive advantage.

Our study seeks explanations for both SME export involvement and for factors affecting the choice between direct and indirect export modes. Although we expected that operating in an increasingly global operation field would contribute to reducing risks and uncertainties associated with operating abroad (e.g., by making it easier for a SME exporter to find information about foreign markets and to locate customers abroad) and would therefore increase the likelihood of SMEs to use the direct rather than the indirect export mode, our results do not support that surrounding actors' internationalization behavior impacts SME export mode choice. Thus, our findings suggest that institutional theory has little relevance in explaining the choice for a specific internationalization mode. We do, however, find some support for resource dependency theory explanations of channel choice.

We find some support for our hypothesis that SMEs based in favorably perceived home markets are more likely to export directly. Specifically, our findings indicate that SMEs are more likely to export using the direct mode if they are located in home markets with favorably perceived production costs and access to knowledge and technology. Our finding that perceived favorability of production costs at home may be particularly relevant for the direct export mode suggests that lower production costs result in an immediate cost advantage for exporters, which may help build a competitive advantage for the firm's product overseas. Direct exporting may therefore become easier, and the need to use intermediaries to export may decrease. Also, markets in which exporters compete on production costs or prices may be more transparent, lessening the need to rely on intermediaries to export. The finding that perceived favorable access to knowledge and technology increases the odds for using the direct export mode suggests that SME exporters operating in such home markets may be more able to develop unique or new products or services that provide direct export opportunities and reduce reliance on intermediaries. The direct mode requires firms to possess a more full set of resources and capabilities (Acs and Terjesen 2006), and the presence of favorable home market conditions likely helps firms to develop such resources and capabilities. Indeed, our results suggest that SME exporters are particularly dependent on favorable home market production costs and favorable home market access to knowledge and technology, which enable them to export directly. In contrast, the presence of customers, suppliers, raw materials and favorable regulations do not favor the direct mode.

In contrast to our prior predictions, we find that perceived favorability of home market access to investors and banks increases SME odds of using indirect rather than direct channels. We expected that perceived favorable access to investors and banks would help SMEs to access financial resources that they could use, for example, for developing products and competences and for collecting foreign market information and therefore would make it easier for SMEs to export independently. However, our findings suggest that perceived favorable access to finance stimulates SMEs to dedicate any financial resources that they may be able to access to hiring intermediaries or perhaps that such investors and banks provide connections to intermediaries. Although our data on motivations for using intermediaries indicate that intermediaries may have a function in reducing certain costs, the finding that 
SMEs prefer indirect rather than direct export when finance is perceived to be easily accessible at home may suggest that, overall, hiring intermediaries is perceived to be more costly than exporting directly, perhaps due to the extra resources required to coordinate and monitor this relationship.

Our findings point towards a number of policy implications. To promote SME export activity, governments could facilitate in setting up networks between non-internationally active SMEs and internationally active domestic firms (customers, competitors and suppliers) that operate within the same organization field. Furthermore, the promotion of SME import activity is likely to contribute to SME export. Both direct and indirect export activities are important for national economies. Our findings suggest that governments wishing to help SME exporters to export independently could devote efforts to improving SME access to knowledge and technology and to lowering production costs in the home market. Governments keen to promote the use of export intermediaries among domestic SME exporters (e.g., because this is important for helping SMEs to locate customers abroad, to reduce uncertainties and risks of foreign operations and to overcome knowledge barriers) should focus on facilitating favorable investor access in the home market.

\section{Conclusion}

Our article develops and tests resource dependency and institutional theory arguments for explaining SME export involvement and export mode. Overall, the findings suggest that institutional theory perspectives (SME owner/managers' perception of the increased international presence of their domestic competitors, customers and suppliers and perception of increased use of foreign suppliers) explain the decision to export, while resource dependency theory arguments (SME owner/managers' perception of the favorability of access to knowledge and technology, of production costs and of access to capital in the home market) guide the choice between direct and indirect export modes.

Our study makes a number of contributions to existing research. First, by incorporating and integrating resource dependency and institutional theory perspectives to explain SME export involvement and channel choice, we build on existing literature by considering the role of external factors on SME internationalization. We have argued that SMEs may be particularly dependent on the external environment in order to overcome certain resource constraints. Also, SMEs are more likely to benefit from knowledge spillovers from external actors (Acs et al. 1994). Whereas in large firms, external knowledge spillovers must compete with internal knowledge spillovers from prior and ongoing operations and may therefore be less important, the knowledge production function of smaller firms is likely to be influenced by input that is provided by external organizations (Acs et al. 1994). As extant empirical work focuses on individual- and firm-level factors, our study contributes to the much neglected role of external factors.

Our study is subject to a number of limitations. First, we focus on SMEs in The Netherlands, a unique market, and therefore our findings may not be generalizable to other environments. Second, due to the cross-sectional nature of our data, it is not possible to establish conclusively any causal relationships. Third, while we recognize that it is the perception of the entrepreneur that determines his behavior and have therefore mainly included perception variables in our dataset, future studies could also seek to collect and test more objective measures about factors relating to the favorability of the home market and the global nature of the organization field. It could also be worthwhile to study the origin of perceptual differences of the external environment. While varying perceptions are likely to stem from actual differences in firms' unique task environments, they may also be influenced by other factors, such as the owner/manager's personal experiences. For example, owner/managers with successful experience in obtaining finance in the home market may perceive more favorable access to investors in the home market than do owner/managers who were unsuccessful or have little experience in acquiring finance. Furthermore, we do not take into account the targeted overseas market. Finally, as our measures were collected through a single questionnaire, the study is susceptible to common method bias.

Going forward, our study suggests a number of future research directions. Further investigations could focus more on the role of intermediaries in influencing SME export behavior. Intermediaries that are 
proactive in seeking clients may, for example, drive higher volumes of SME clients' exports. Also, some of the knowledge of intermediaries, e.g., on a particular market may spill over to their SME clients and may consequently increase the odds for SMEs to export directly to this market. This article also explores the role of MNEs in facilitating SME internationalization. However, SMEs may not only use MNEs, but also they may be MNE targets for cross-border mergers and acquisitions (OECD 2004; Acs et al. 1997). Future research should examine how MNE-SME internationalization linkages are developed. Furthermore, the choice of direct or indirect export mode could be examined with respect to firm performance and macroeconomic outcomes (e.g., economic growth and innovation). In addition, resource dependency theory and institutional theory differ in terms of predicted outcomes on firm performance. Whereas resource dependency theory argues that to prosper or survive organizations need to obtain resources from external sources, institutional theory argues that actions leading to isomorphism are not necessarily efficient. Thus, while institutional theory predicts that a firm may be stimulated by its global organization field to undertake some activities to be seen as a global player, the implications on operational performance may actually be negative. Future research could seek to provide insight into the actual impact on firm performance of organizational behavior that follows the logic of resource dependency and institutional theory.

Acknowledgments This article was written in the framework of the SCALES research program undertaken by EIM and financed by the Dutch Ministry of Economic Affairs. Previous versions of this paper were presented at the 2007 Babson College Entrepreneurship Research Conference (Madrid, Spain) and the 2008 Academy of Management Annual Meeting (Anaheim, California).

Open Access This article is distributed under the terms of the Creative Commons Attribution Noncommercial License which permits any noncommercial use, distribution, and reproduction in any medium, provided the original author(s) and source are credited.

\section{References}

Acs, Z. J., Audretsch, D. B., \& Feldman, M. P. (1994). R\&D spillovers and recipient firm size. Review of Economics and Statistics, 76(2), 336-340.
Acs, Z. J., Morck, R., Shaver, J. M., \& Yeung, B. (1997). The internationalization of small and medium-sized enterprises: A policy perspective. Small Business Economics, 9(1), 7-20. doi:10.1023/A:1007991428526.

Acs, Z. J., \& Terjesen, S. (2006). Born local: Two views of internationalization. Working Paper presented at the Academy of Management, Atlanta, Georgia.

Aitken, B., Hanson, G. H., \& Harrison, A. E. (1997). Spillovers, foreign investment and export behavior. Journal of International Economics, 43, 103-132. doi:10.1016/ S0022-1996(96)01464-X.

Akoorie, M., \& Enderwick, P. (1992). The international operations of New Zealand companies. Asia Pacific Journal of Management, 9(1), 51-69. doi:10.1007/BF017 32037.

Autio, E., Sapienza, H. J., \& Almeida, J. G. (2000). Effects of age at entry, knowledge intensity, and imitability on international growth. Academy of Management Journal, 43(5), 909-924. doi:10.2307/1556419.

Axinn, C. N. (1988). Export performance: Do managerial perceptions make a difference? International Marketing Review, 5, 67-71. doi:10.1108/eb008353.

Balabanis, G. I. (2000). Factors affecting export intermediaries' service offerings: The British example. Journal of International Business Studies, 31(1), 83-99. doi:10.1057/ palgrave.jibs.8490901.

Barney, J. B., \& Arikan, A. M. (2001). The resource-based view: Origins and implications. Blackwell handbook of strategic management. Oxford: Blackwell Publishing.

Bello, D. C., \& Lohtia, R. (1995). Export channel design: The use of foreign distributors and agents. Journal of the Academy of Marketing Science, 23(2), 83-93. doi:10.1177/ 0092070395232001.

Blomstermo, A., Sharma, D. D., \& Sallis, J. (2006). Choice of foreign market entry mode in service firms. International Marketing Review, 23(2), 211-229. doi:10.1108/02651 330610660092.

Bloodgood, J. M., Sapienza, H. J., \& Almeida, J. G. (1996). The Internationalization of new high-potential U.S. ventures: Antecedents and outcomes. Entrepreneurship Theory and Practice, 20(4), 61-76.

Cavusgil, T., \& Nevin, J. R. (1981). Internal determinants of export marketing behavior: An empirical investigation. Journal of Marketing Research, 18(1), 114-119. doi: $10.2307 / 3151322$.

Chang, S. (1995). International expansion strategy of Japanese firms: Capability building through sequential entry. Academy of Management Journal, 38(2), 383-407. doi: $10.2307 / 256685$.

Chetty, S. K., \& Hamilton, R. K. (1993). Firm level determinants of export performance: A meta-analysis. International Marketing Review, 10(3), 26-34. doi:10.1108/ 02651339310040643.

Coviello, N. E., \& McAuley, A. (1999). Internationalisation and the smaller firm: A review of contemporary empirical research, management. International Review (Steubenville, Ohio), 39(3), 223-256.

Davis, P. S., Desai, A. B., \& Francis, J. D. (2000). Mode of international entry: An isomorphism perspective. Journal of International Business Studies, 31(2), 239-258. doi: 10.1057/palgrave.jibs.8490904. 
De Clercq, D., Hessels, J., \& van Stel, A. (2008). Knowledge spillovers and new ventures' export orientation. Small Business Economics, 31(1), 283-303. doi:10.1007/s11187008-9132-z.

De Clercq, D., Sapienza, H., \& Crijns, H. (2005). The internationalization of small and medium-sized firms. Small Business Economics, 24, 409-419. doi:10.1007/s11187005-5333-x.

DiMaggio, P., \& Powell, W. (1983). The iron cage revisited: Institutional isomorphism and collective rationality in organizational fields. American Sociological Review, 48, 147-160. doi:10.2307/2095101.

Eriksson, K., Johanson, J., Majkgård, A., \& Sharma, D. D. (1997). Experiential knowledge and cost in the internationalization process. Journal of International Business Studies, 28(2), 337-360. doi:10.1057/palgrave.jibs. 8490104.

Etemad, H. (2004). Internationalization of small and mediumsized enterprises: A grounded theoretical framework and an overview. Canadian Journal of Administrative Sciences, 21(1), 1-21.

Etemad, H. (2005). SMEs' internationalization strategies based on a typical subsidiary's evolutionary life cycle in three distinct stages, management. International Review (Steubenville, Ohio), 45(3), 145-186.

Fletcher, D. (2004). International entrepreneurship and the small business. Entrepreneurship and Regional Development, 16, 289-305. doi:10.1080/0898562042000263267.

Fujita, M. (1995). Small and medium sized transnational corporations: Trends and patterns of foreign direct investment. Small Business Economics, 7(3), 183-204. doi:10.1007/BF01135364.

George, G., Wiklund, J., \& Zahra, S. (2005). Ownership and internationalization of small firms. Journal of Management, 31(2), 210-233. doi:10.1177/0149206304271760.

Gimeno, J., Hoskisson, R. E., Beal, B. D., \& Wan, W. P. (2005). Explaining the clustering of international expansion moves: A critical test in the U.S. telecommunications industry. Academy of Management Journal, 48(2), 297-319.

Greenaway, D., Sousa, N., \& Wakelin, K. (2004). Do domestic firms learn to export from multinationals? European Journal of Political Economy, 20(4), 1027-1043. doi: 10.1016/j.ejpoleco.2003.12.006.

Hessels, J. (2005). Internationalisation of Dutch SMEs, RePEC (Research Papers in Economics), Research Report M200507, EIM Business and Policy Research, Zoetermeer, The Netherlands.

Hinings, C. R., \& Greenwood, R. (1988). The dynamics of strategic change. New York: Blackwell.

Hollenstein, H. (2005). Determinants of international activities: Are SMEs different? Small Business Economics, 24(5), 431-450. doi:10.1007/s11187-005-6455-x.

Johanson, J., \& Vahlne, J.-E. (1977). The internationalization process of the firm: a model of knowledge development and process of the firm: A model of knowledge development and increasing foreign market commitments. Journal of International Business Studies, 8(1), 23-32.

Johanson, J., \& Wiedersheim-Paul, F. (1975). The internationalization of the firm: Four Swedish cases. Journal of Management Studies, 12(3), 305-322. doi:10.1111/ j.1467-6486.1975.tb00514.x.
Keeble, D., Lawson, C., Smith, H., Moore, B., \& Wilkinson, F. (1998). Internationalisation processes, networking and local embeddedness in technology-intensive small firms. Small Business Economics, 11(4), 327-342. doi:10.1023/ A:1007942612220.

Kneller, R., \& Pisu, M. (2007). Industrial linkages and export spillovers from FDI. World Economy, 30(1), 105-134. doi:10.1111/j.1467-9701.2007.00874.x.

Knight, G. (2000). Entrepreneurship and marketing strategy: The SME under globalization. Journal of International Marketing, 8(2), 12-32. doi:10.1509/jimk.8.2.12.19620.

Korhonen, H., Luostarinen, R., \& Welch, R. (1996). Internationalisation of SMEs: Inward-outward patterns and government policy, management. International Review (Steubenville, Ohio), 36(4), 315-329.

Kotabe, M. (1992). Global sourcing strategy: $R \& D$, manufacturing, and marketing interfaces. New York: Quorum Books.

Lefebvre, E., \& Lefebvre, L.-A. (2002). Innovative capabilities as determinants of export performance and behaviour: A longitudinal study of manufacturing SMEs. In A. Kleinknecht \& P. Mohnen (Eds.), Innovation and firm performance: Econometric explorations of survey data. London: Palgrave.

Li, L. (2004). Research note: The Internet's impact on export channel structure, Thunderbird. International Business Review, 46(4), 443-463.

McDougall, P. P. (1989). International versus domestic entrepreneurship: New venture strategic behavior and industry structure. Journal of Business Venturing, 4(6), 387-400. doi:10.1016/0883-9026(89)90009-8.

McDougall, P. P., \& Oviatt, B. M. (1996). New venture internationalization, strategic change, and performance: A follow-up study. Journal of Business Venturing, 11, 34-40. doi:10.1016/0883-9026(95)00081-X.

OECD. (2000). OECD small and medium enterprise outlook. Paris: OECD.

OECD. (2004). Promoting entrepreneurship and innovative SMEs in a global economy: To-wards a more responsible and inclusive globalisation. Paris: OECD.

Oliver, C. (1997). Sustainable competitive advantage: Combining institutional and resource based views. Strategic Management Journal, 18(9), 697-713.

Peng, M. W. (2005). Global Strategy. Cincinnati: Thomson.

Peng, M. W., \& Ilinitch, A. Y. (1998). Export intermediary firms: A note on export development research. Journal of International Business Studies, 29(3), 609-620. doi: 10.1057/palgrave.jibs.8490010.

Peng, M. W., \& York, A. S. (2001). Behind intermediary performance in export trade: Transactions, agents and resources. Journal of International Business Studies, 32(2), 327-346. doi:10.1057/palgrave.jibs.8490955.

Pfeffer, J., \& Salancik, G. (1978). The external control of organizations: A resource dependence perspective. New York: Harper and Row.

Porter, M. E. (1990). The competitive advantage of nations. New York: Macmillan.

Porter, M. E. (1998). On competition. Boston, MA: Harvard Business Review Press.

Reynolds, P. D. (1997). New and small firms in expanding markets. Small Business Economics, 9(1), 79-84. doi: 10.1023/A:1007916217140. 
Rialp, A., Rialp, J., \& Knight, G. A. (2005). The phenomenon of early internationalizing firms: What do we know after a decade (1993-2003) of scientific inquiry? International Business Review, 14, 147-166. doi:10.1016/j.ibusrev. 2004.04.006.

Rugman, A. M., \& Wright, R. W. (1999). Research in global strategic management: International entrepreneurship. Stamford, CT: JAI Press.

Scott, W. R. (1995). Institutions and organizations. Thousand Oaks, CA: Sage.

Sharma, V. M., \& Erramilli, M. K. (2004). Resource-based explanation of entry mode choice. Journal of Marketing Theory and Practice, 12(1), 1-18.

Sherer, P. D., \& Lee, K. (2002). Institutional change in large law firms: A resource dependency and institutional theory perspective. Academy of Management Journal, 45(1), 102-119. doi:10.2307/3069287.

Simpson, C. L., \& Kujawa, D. (1974). The export decision process: An empirical inquiry. Journal of International Business Studies, 5(1), 107-117. doi:10.1057/palgrave. jibs.8490815.

Terjesen, S., \& Hessels, J. (2009). Varieties of export-oriented entrepreneurial activity in ten Asian countries: The role of institutional structures. Asia Pacific Journal of Management, 25(2), forthcoming.

Terjesen, S., O'Gorman, C., \& Acs, Z. J. (2008). Intermediated mode of internationalization: New software ventures in Ireland and India. Entrepreneurship and Regional Development, 20, 89-109. doi:10.1080/08985620701630946.

Tesfom, G., Lutz, C., \& Ghauri, P. (2004). Comparing export marketing channels: Developed versus developing countries. International Marketing Review, 21(4-5), 409-422. doi:10.1108/02651330410547117.

Thirkell, P. C., \& Dau, R. (1998). Export performance: Success determinants for New Zealand manufacturing exporters. European Journal of Marketing, 32(9/10), 813-829. doi: 10.1108/03090569810232273.
Trabold, H. (2002). Export intermediation: An empirical test of Peng and Ilinitch. Journal of International Business Studies, 33(2), 327-344. doi:10.1057/palgrave.jibs.8491019.

UNCTAD (2008). United Nations Conference on Trade and Development. Handbook of Statistics 2006-2007.

Van Witteloostuijn, A., \& Boone, C. (2006). A resource-based theory of market structure and organizational form. Academy of Management Review, 31(2), 409-426.

Westhead, P. (1995). Exporting and non-exporting small firms in Great Britain. International Journal of Entrepreneurial Behavior and Research, 1(2), 6-36. doi:10.1108/13552 559510090604.

Westhead, P., Wright, M., \& Ucbasaran, D. (2004). Internationalization of private firms: Environmental turbulence and organizational strategies and resources. Entrepreneurship and Regional Development, 16, 501-522. doi: 10.1080/0898562042000231929.

Westney, D. E. (2003). Japanese enterprise faces the twentyfirst century. In P. DiMaggio (Ed.), The twenty-first-century firm: Changing economic organization in international perspective. Princeton: Princeton University Press.

Wilkinson, T. J. (2006). Entrepreneurial climate and U.S. State Foreign Trade Offices as predictors of export success. Journal of Small Business Management, 44(1), 99-113. doi:10.1111/j.1540-627X.2006.00156.x.

Yli-Renko, H. K., Autio, E., \& Tontti, V. (2002). Social capital, knowledge acquisition, and the international growth of technology-based new firms. International Business Review, 11, 279-304. doi:10.1016/S0969-5931(01) 00061-0.

Zacharakis, A. (1998). Entrepreneurial entry into foreign markets: A transaction costs perspective. Entrepreneurship Theory and Practice, spring, 23-39. 